\title{
IAMJ
}

INTERNATIONAL

AYURVEDIC

MEDICAL JOURNAL

ISSN: $2320-5091$

Impact Factor: 6.719

\section{EFFECT OF TANKAN BHASMA IN THE MANAGEMENT OF MUKHPAK (STOMATITIS): AN OBSERVATIONAL STUDY}

Tushar Suresh Punse

Dept. Kayachikitsa Shri Gurudev Ayurved College, Gurukunj Ashram Mozari, MUHS NASHIK, Maharashtra, India

Corresponding Author: tusharpunse4@gmail.com

https://doi.org/10.46607/iamj0408122020

(Published online: December 2020)

Open Access

(C) International Ayurvedic Medical Journal, India 2020

Article Received: 11/11/2020 - Peer Reviewed: 16/11/2020 - Accepted for Publication: 18/11/2020

D) Check for updates

\begin{abstract}
Mukhpak (Stomatitis) is most common disease of oral cavity and can occur anywhere in the mouth, including the inside of the cheeks, gums, lips, palate and tongue. It can disrupt a person's ability to talk, eat and sleep. This is an observational study on 65 Mukhpak (stomatitis) patients with complaints of redness, ulceration in oral cavity, salivation, pain and burning sensation in mouth treated with 3 - 4 times local application of Tankan Bhasma with Madhu (Honey) up to 14th days. Study demonstrated that local application of Tankan Bhashma with honey is the so fast, simplest, economical and effective drug therapy in the management of Mukhpak due to anti-inflammatory, analgesic as well as healing property of Tankan Bhasma and Madhu.
\end{abstract}

Keywords: Mukhpak, Stomatitis, Tankan Bhasma, Madhu

\section{INTRODUCTION}

In modern life style, excessive intake of fast foods, cold drinks spicy foods mixed type of food, acidic foods, etc. and addictions of chewing betel nut, Gutkha, tobacco, smoking, drinking alcohol etc. which are characterised as Apthyakar in Ayurveda disturb the normal physiology of the body and causes many oral diseases. Stomatitis is considered as one of the prevalent oral disease worldwide characterized by redness, ulceration in oral cavity with burning sensation, salvation and pain. Stomatitis occurs anywhere in 
the mouth, including the inside of cheeks, gums, tongue, lips and palate. The symptoms degree from presence of mouth ulcers, redness and erosions of buccal mucosa, burning sensation of oral mucosa, difficulty in chewing pungent and hot things and or enlargement of sublingual and submandibular lymph nodes. In Allopathic system of medicine, various vitamins, systematic antibiotics, tetracycline mouth wash, local application of thick layer of triamcinolone acetoride, local anti- inflammatory agents like kena$\log$, orabase etc., are being recommended in this disease. However, ayurvedic treatments for this disease are safe, effective, cheap and non- toxic. Mukhpaka often called as sarvsara roga is a disease of oral cavity characterised in Ayurveda as the paka-avastha of oral mucosa and produces ulcers in oral cavity. Pitta dosha, raktavah and mamsa are the main dushya in Mukhpak. According to Acharya Sushruta there are 65 mukhroga which occur at seven locations such as lips, teeth, tongue, palate, throat and oral cavity and out of them 8 occur in lips, 15 in gums, 8 in teeth, 3 in tongue, 9 in palate, 17 in throat and 3 in entire mouth as described in uttartantra. To break this samprapti, pitta doshahar, rakta prasadak, vranashodhak, vranropak, shothahar chikitsa is essential. As per Ayurveda the line of treatment for mukhpak should be pittashamaka, Shothahara, Vedanasthapana, vranashodhana, Vranaropana, Rakta prasadaka, Mamsa dhatu pustikara. The clinical symptom of Mukhpak is comparable with stomatitis. There are many drugs described in Ayurveda literature to cure Mukhpak (Stomatitis) effectively. Sushruta praised the effect of Kshara (alkalis) so much that it can be replace Shastra karma since it does the chedna, bhedna, lekhna, dara$n a$, shothahara and roopna karmas simultaneously without the help of Shashtra.

Tankana (Na2B4O7.10H2O; Sodium tetraborate decahydrate) or purified borax a commonly available alkali appreciated as kshara raja or kshara shresta It has own important role because of its high therapeutic value. It is a medicine that is used for the treatment of skin diseases, ulcerating sores, gingivitis, eczema, cough etc. Honey, known as madhu is one of the most important medicines used in Ayurveda for both internal and external applications and mainly used for the treatment of eye diseases, cough, thirst, phlegm, hiccups, worm infestation, vomiting, epistaxis, leprosy, obesity, asthma, healing. wounds and diarrhoea. It is also used as a vehicle along with some medicines to improve its efficacy or to mitigate the side effects of the other medicines. In the present observational study, therapeutic potential of Ayurvedic medicine i.e. Tankan Bhasma along with madhu in 65 patients suffering from Mukhpak (stomatitis) is described

\section{Material and Methods}

This is an observational study based on daily OPD practice on 65 patients of age range 13-73 years with complaints of redness, ulceration in oral cavity, salivation, pain and burning sensation in mouth during chewing of food for the last 3 months visited OPD of Shri Gurudev Ayurved College department of Kayachitsa for treatment. Gender wise distributions of patients along with their socioeconomic conditions were presented in Table 1. Based on the symptoms and clinical feature they are diagnosed with the disease Mukhpak (Stomatitis). Patients were treated with oral application of $500 \mathrm{mg}$ Tankan Bhasma with $2 \mathrm{ml}$ madhu for three to four times in a day and advised to stop sour, hot and spicy food article. Present study was carried out in accordance with ethical principles by following International conference of Harmonization-Good Clinical Practices Guidelines (ICH-GCP).

Criteria for Assessment: The treatment result was assessed in the form different levels of grades assigned to the clinical sign and symptoms.

\section{Clinical Assessment}

Clinical assessment was done on alternate 0 day and 14th day. Follow up of the patients was also performed on 7th days. Change in symptoms before and after treatment were recorded at each follow up and recorded in the form of qualitative data and further converted to quantitative data for statistical analysis. Grading was given for every clinical feature. The signs and symptoms were assessed by adopting suitable scoring method. The details are as follows. 


\begin{tabular}{|c|c|}
\hline Symptom & Grading \\
\hline Redness & $\begin{array}{l}0 \text { No redness. } \\
1 \text { Mild redness. } \\
2 \text { Moderate redness. } \\
3 \text { Severe redness. } \\
4 \text { Extreme redness }\end{array}$ \\
\hline Ulcer in mouth & $\begin{array}{l}0 \text { No ulceration in oral cavity. } \\
11-2 \text { ulcers in oral cavity. } \\
2 \text { 2-3 ulcers in oral cavity. } \\
34-5 \text { ulcers in oral cavity. } \\
4 \text { More than } 5 \text { ulcers in oral cavity }\end{array}$ \\
\hline Salivation & $\begin{array}{l}0 \text { No salivation in oral cavity. } \\
1 \text { Wild salivation ( } 1-2 \text { times spitting) in a day. } \\
2 \text { Moderate (3-4 times spitting) in a day. } \\
35 \text { to } 7 \text { times spitting in a day }\end{array}$ \\
\hline Pain & $\begin{array}{l}0 \text { No pain in ulcers in mouth. } \\
1 \text { Mild pain in ulcers in mouth. } \\
2 \text { Moderate pain in ulcers in mouth. } \\
3 \text { Severe pain in ulcers in mouth. } \\
4 \text { Extreme pain is ulcers in mouth }\end{array}$ \\
\hline $\begin{array}{l}\text { Burning sensation during food } \\
\text { intake }\end{array}$ & $\begin{array}{l}0 \text { No pain in ulcers in mouth. } \\
1 \text { Mild pain in ulcers in mouth. } \\
2 \text { Moderate pain in ulcers in mouth. } \\
3 \text { Severe pain in ulcers in mouth. } \\
4 \text { Extreme pain is ulcers in mouth }\end{array}$ \\
\hline
\end{tabular}

Statistical analysis: The data obtained was analyzed for significance between the groups by student t-test using statistical software programme "SPSS evaluation version 22 ".

Results: Results of the observational study showed that among 65 patients of stomatitis included in this study, male and female were 32 and 33 respectively (Table 1). The age ranges of male and female subject were 25-73 years and 13-63 years respectively. Figure 1 shows the occupation wise distribution of Mukhpak patients. It was observed that Mukhpak is a common disease in all the age groups of present era.

Table 1: Gender wise distribution of the patients selected for the study

\begin{tabular}{|l|l|l|}
\hline Gender & No. of Patient & Age range \\
\hline Male & 32 & $25-73$ \\
\hline Female & 33 & $13-63$ \\
\hline Totel & 65 & $13-73$ \\
\hline
\end{tabular}

Figure 1: Occupation wise distribution of Mukhpak patients

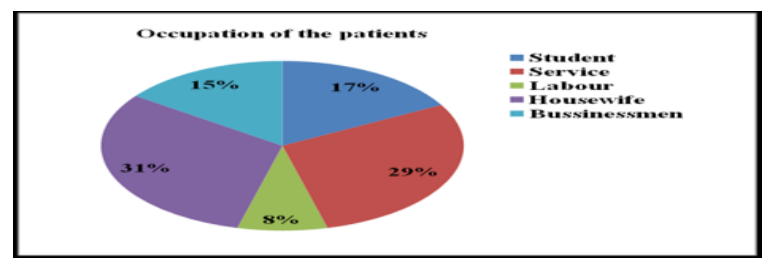

Results of the Table 2 showed that the local application of Tankan Bhasma with Madhu have resulted in clinically marked improvement in the symptoms of Mukhpak which are statistically significant $(\mathrm{P}<$ 0.001). There was a rapid decline in redness (98.82 $\%$ ), ulceration in oral cavity (98.44 5), salivation (99.21\%), pain (99.60) and burning sensation in mouth during chewing of food $(95.47 \%)$. 
Table 2: Efficacy evaluation of Tankan Bhasma along with Madhu in symptoms of Mukhpak (stomatitis)

\begin{tabular}{|l|l|l|l|}
\hline Symptoms in & Before & After treatment & \% Relief \\
\hline Redness & $3.94 \pm 0.03$ & $0.05 \pm 0.03^{*}$ & $98.82 \%$ \\
\hline Ulcer in mouth & $3.94 \pm 0.03$ & $0.06 \pm 0.04^{*}$ & $98.44 \%$ \\
\hline Salivation & $3.90 \pm 0.01$ & $0.03 \pm 0.02^{*}$ & $99.21 \%$ \\
\hline Pain & $3.88 \pm 0.04$ & $0.02 \pm 0.01^{*}$ & $99.60 \%$ \\
\hline Burning & $3.73 \pm 0.12$ & $0.17 \pm 0.01^{*}$ & $95.47 \%$ \\
\hline
\end{tabular}

Values are represented as Mean $\pm \mathrm{SE} . * \mathrm{P}<0.001$ as compared to the symptoms of the before treatment

\section{DISCUSSION}

Mukhpak (Stomatitis) is a very common disease of oral cavity in India as well as Asia due to heavy consumption of pitta prakopakaahar like spicy oily food, tobacco chewing, smoking, alcohol consumption, fast food etc. and also pitta prakopak vihar like late night sleeping, improper timing of meals, lack of exercise etc. According to Ayurveda, in this condition Mukha is affected by Paka process which is always associated with pitta Dosha and patient feels irritation, pain and burning sensation during food intake. It may also occur due to addiction like tobacco, wine etc. Insomnia, vitamins deficiency, and life-threatening disease like malignancy, sub mucosal fibrosis disturbances in gastrointestinal tract. It is very important to have effective, economic \& without any side effect, medicine on it. So here an attempt is made to treat stomatitis with Tankan Bhasma with Madhu.

Tankan Bhasma has both bleaching and antiseptic properties which ultimately eradicate pathogens. Honey has been described in ancient and modern medicine as being effective in the healing of various infected wounds, healing of burns, ulcers and open wounds, which believed to be related to its constituents since fructose, the predominant sugar in honey, is very hygroscopic. Madhu or honey is probably adsorbing toxins from the mucous membrane and precipitate protein, so the pus and inflammatory exudates became adsorbed by the natural honey, thus protecting the underlying tissues and enhanced normal healing and the epithelialization.

The natural honey is sticky viscous solution that is the way to make it adherent to the ulcer. Coating the ulcer and prevention of secondary infection is the probable mechanism of action of Madhu. No allergic mucosal reaction or toxic effects have been reported with the usage. Results of the present study demonstrated highly effective, therapeutic and significant potential of Ayurvedic medicine in management of Mukhpak or stomatitis. It may be due to anti- inflammatory, analgesic as well as healing property of Tankan Bhasma and Madhu. Study demonstrated and confirms that local application of Tankan Bhasma with Madhu is the so fast, simplest, economical and effective drug therapy in the management of Mukhpak.

\section{CONCLUSION}

Present observational study showed that stomatitis is of the commonest oral diseases in India and found in all the age groups. Local application of Tankan Bhas$m a$ with Madhu is effective medications for the treatment of Mukhpak (stomatitis). These remedies are being practiced in Ayurveda and are cost effective and easily available.

\section{Recommendation}

The present study is an observational study based on the clinical practice. Moreover, a well-structured standardized randomized placebo-controlled study is recommended.

\section{REFERENCES}

1. Acharya YT, Editor. Sushrutha Samhita of Sushruta, Uttar Tantra, Ch. 34, Ver. 5. 2nd ed. Varanasi: Chaukhambha Sanskrit Sansthan; 2004, p. 224.

2. Sushrut Samhita of Sushruta with Nidan Sangraha commentary of Shri. Dalhan Acharya \& Nyaya Chandrika Panjika of Shri. Acharya on Nidansthana, Edited by Yadaji Trikamji Acharya, Nidanasthana 16, p. 314.

3. Shastri AD. Commentator. Bhaishajya ratnavali of Govinda Das Sen, Ch. 10, Ver. 269-272. 2nd ed. Varanasi: Chaukhamba Sanskrit Sansthan; 2010. p 361. 
4. RR Pathak, Ayurved Sar Sangrah, Baidhyanath ayurved bhawan limited, Nagpur, 1978, p 610.

5. Bhargav KB, Bhargav SK, Shah TM, Textbook of diseases of Ear-Nose-Throat, 6th Edition, Chapter No. 37, Page No.211.

6. Ashtang hridaya with commentary of Arundatta \& Hemadri Nirnay Sagar Press, Bombay, Uttarsthana 21, 22, Page No.855.

7. Salcido R. Complementary and alternative medicine in wound healing (editorial). Adv wound - care J. 1999; 12 (9):438.

8. AL-Waili NS, Saloom KY. Effects of topical honey on post-operative wound infection due to gram positive and gram-negative bacteria following cesarean section and hysterectomies. Eur J Med Res. 1999; 26: 4(3):126-130.

\section{Source of Support: Nil}

\section{Conflict of Interest: None Declared}

How to cite this URL: Tushar Suresh Punse: Effect Of Tankan Bhasma In The Management Of Mukhpak (Stomatitis): An Observational Study. International Ayurvedic Medical Journal \{online\} 2020 \{cited December, 2020\} Available

from: $\underline{\text { http://www.iamj.in/posts/images/upload/5227_5231.pdf }}$ 